\title{
Actually Innocent Prisoners: Will the State Get it Right? Mwandishi Mitchell
}

Tn September of 2011 a Report of the Advisory Committee on Wrongful Convictions came down through the General Assembly of the Commonwealth of Pennsylvania. The Advisory Committee, made up of a who's who of political big shots, with names like Edward Marsico Jr., the District Attorney of Dauphin County, Seth Williams, the District Attorney of Philadelphia, and David Rudovsky, a prominent civil rights attorney proposed legislation that would curb the travesty of wrongful convictions. The forty-eight team panel, with John T. Rago, Esq. sitting as its chair, put together a three-hundred-one page dossier on wrongful convictions in Pennsylvania and other states. The dossier focuses on the main causes for wrongful convictions such as eyewitness identification, electronic recording of custodial interrogations, post-conviction relief, legal representation, science, and for those who prove their innocence, redress.

Pennsylvania Senator Stewart J. Greenleaf spearheaded this movement years before with the introduction of Senate Bill No. 381 in 2006. At that time eight individuals were exonerated in Pennsylvania through postconviction DNA testing, three of which were incarcerated for murder and one of whom was on death row (Garis, 2003). The Advisory Committee also cites this important fact:

\footnotetext{
Since 1989, 34 states and District of Columbia have been witness to 273 post-conviction DNA exonerations. These exonerations represent cases in which the conviction has been indisputably determined to be wrong by continuing advances in the use of DNA science and evidence. They represent tragedy not only for the person whose life is irreparably damaged by incarceration for a crime he did not commit, but also for the victim since each wrongful conviction also represents the failure to convict the true perpetrator (p. 1).
}

Reading that had me feeling that at least some in the Pennsylvania Legislature felt my pain. I have spent ten years in a Department of Corrections prison cell for a wrongful conviction. You would think this news brightens my spirits, but it does not. I know all too well the politics involved in some cases of wrongful convictions. The quid pro quo factor will leave many of us here languishing in agony. 
As it stands in Pennsylvania, DNA testing is not a right pertaining to wrongfully convicted prisoners. My own petition for DNA testing has been denied by the trial court. The Advisory Committee seeks to make DNA testing a right by amending the current statute to clarify: 1) the right to petition for DNA testing post-conviction and 2) that DNA test results be compared to profiles in the state DNA database pre- and post-conviction.

To put it bluntly, an innocent defendant convicted of a crime becomes an innocent victim himself. They will sit for years on end in some prison cell with all hope of being exonerated lost. When you are in a prison environment, anything can happen to you. Imagine stepping out of your cell on your way to chow and someone slamming a homemade "shank" into your gut over a petty argument from two nights prior or, even worse, being beaten down to the ground by institutional staff for any reason they are able to come up with to justify their actions. These are the things that could happen to an innocent inmate on "Any Given Sunday".

Wrongful convictions are not some new phenomenon in Pennsylvania, or any other state, but the point is it happens, and when it does, states should be responsible and compensate the wrongfully convicted with redress. Under the current existing law, most of the individuals who are freed after being found innocent of the crimes for which they were convicted are unable to obtain any compensation from government or other sources for the losses they sustained. The Advisory Committee settled on three main areas for consideration: 1) financially compensating the wrongly convicted; 2) providing transitional services for those released; and 3) establishing a commission to review cases of those found to be innocently convicted, so that the Commonwealth can learn from its errors and prevent them from happening again.

The Advisory Committee recommends that the Commonwealth statutorily compensate any person who is released from imprisonment due to a wrongful conviction. Under the current proposal, the Committee agrees on a payment of $\$ 50,000$ a year for each year the wrongfully convicted had to spend in jail. But honestly, can anyone put a price on you being deprived of your liberty? Of course not. In Pennsylvania, only four of the eleven individuals exonerated by way of post-conviction DNA testing received compensation. There is something wrong with that picture.

For wrongfully convicted prisoners, there is a tough, rough road ahead. Even after being exonerated, the mental stress and pain takes a toll. You 
have to adapt to civilization after decades of being locked away. Things as simple as operating a cell phone will require extreme thought and patience.

Personally, I am tired of waiting for Pennsylvania to catch up with the rest of the country. Just across the Delaware River in New Jersey, the attorney general has sole authority over all law enforcement personnel in that state. He has mandated new procedures to crack down on witness identification procedures (nearly 75 percent of wrongful convictions are due to eyewitness misidentification) by using National Institute of Justice guidelines (Innocence Project, 2013). To the West in Ohio, the legislature has adopted statutes that require administrators who oversee perspective witnesses in line-ups and photo arrays remain ignorant of whether or not a particular defendant is present (LAWriter, 2010). Each witness views each folder individually. For each folder, the witness must state whether or not the picture is of the perpetrator and his or her confidence in that identification.

Also, we need the help of the public as well. They vote for the politicians who make the laws of this nation. Many have stereotypical views of prisoners in general, like if the justice system has problems, the pros will fix them; everyone in prison claims to be innocent; an eyewitness is the best evidence; our system almost never convicts an innocent person; it dishonours the victim to question a conviction; only guilty people confess; conviction errors get corrected on appeal; and, the worst, wrongful convictions result from innocent human error.

To the thirteen Pennsylvania exonerees, I salute you. Matthew Connor, Bruce Nelson, Jerry Pacek, Jay C. Smith, Dale Brison, Vincent Moto, Willie Nesmith, William Nieves, Edward Baker, Steven Crawford, Bruce Godschalk, Thomas Kimbell, Jr., and Nicholas Yarris.

The rest of us are still waiting for the Pennsylvania legislature to pass the recommended Advisory Committee legislation.

\section{REFERENCES}

Innocence Project (2013) "Eyewitness Misidentification". Retrieved from http://www. innocenceproject.org/understand/Eyewitness- Misidentification.php?gclid=CKr0op nTjLoCFc6e4AodNlQAmg.

Garis, Jeff (2003) "Exoneration of Pennsylvania death row prisoner anticipated Tuesday; Death penalty moratorium supporters to hold vigil at courthouse", Death Penalty Information Center - December 8. Retrieved from http://www.deathpenaltyinfo.org/ node/136. 
LA Writer (2010) Administration of Photo or Live Lineups, Section 2933.83, Ohio Revised Code. Retrieved from http://codes.ohio.gov/orc/2933.83.

Joint State Government Commission (2011) "Report of the Advisory on Wrongful Convictions", Harrisburg (PA): General Assembly of the Commonweatlth of Pennsylvania, September. Retrieved from http://jsg.legis.state.pa.us/resources/ documents/ftp/documents/9-15- 11\%20rpt\%20-\%20Wrongful\%20Convictions.pdf.

\section{ABOUT THE AUTHOR}

Mwandishi Mitchell continues to fight in court in pursuit of overturning his wrongful conviction. He is also a contributing writer for Minutes Before Six, a blog for death row writers and those serving life without parole. He can be contacted at:

Mwandishi Mitchell \#GB6474, P.O. Box 244,

SCI Graterford, Graterford, PA 19426, USA 